\title{
94. TEW法による散乱線画像のパワースペクトル解析
}

Analysis of scattering image treated with T.E.W. method using power spectrum

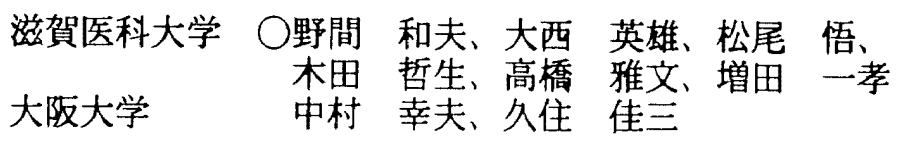

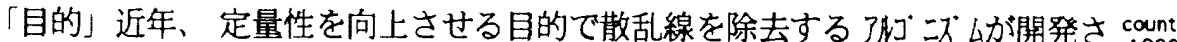

れ、その有用性の証明は放射能瀑度とSPECT值からのみ議論されています。我々 は、前回 Main Window の画像の周波数特性Sub Windowの周波数特性を分析 したが、散乱線補正を行う場合において、画質特性と碾度直線性の面からの解析 も重要と考え検討を行いました。

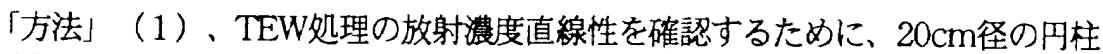
型水ファ忪中に $5 \mathrm{~cm}$ 径の円柱容器を4本配置し、その円柱容器にそれぞれに放射能 の異なる水溶液を封入しました。

（2）、上記の放射濃度直線性の確認ファントム及Brain-Phantomを使用し て、TEW処理を行いそれぞれの(Main,Upper \&Lower-sub) windowの画像に 前処理フィルタ処理し、次に、前処理フィルタであるButterworthフィルタの遮 断周波数を変化させてそれぞれの処理画像を作成しました。

「結果」 fig.1より、蹦床上は $500 \mathrm{kBq} / \mathrm{ml}$ 以下に注目すべきであり、Sub-Windowの遮断周波数の違い $(0.01 、 0.03 \mathrm{cycles} / \mathrm{mm})$ やSPECTとStaticなどにおい ても問題となる程の差は検出できず灌度值線性が保たれていました。fig.2より、 Brain phantomでは、信号成分は0.04cycles/mmまで存在するとわかりました。 fig.3より、TEWを行わないときに比べ、信号が強調されていることがわかり、 TEW処理の有用性が示され、また、Butter worth filterのカットオフ周波数が 0.04 cycles $/ \mathrm{mm}$ の方が 0.01 cycles $/ \mathrm{mm}$ より信号が強調されていました。fig.4よ り、Butter worth filterの遮断周波数0.04cycles $/ \mathrm{mm}$ では0.01cycles $/ \mathrm{mm}$ に比べ 散乱成分を多く除去できるが、信号成分も多く引くため、ある程度、高い力ウン

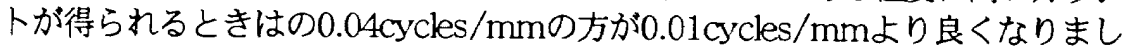
たが、カウントの低いときは、逆に0.07の方が良くなりました。

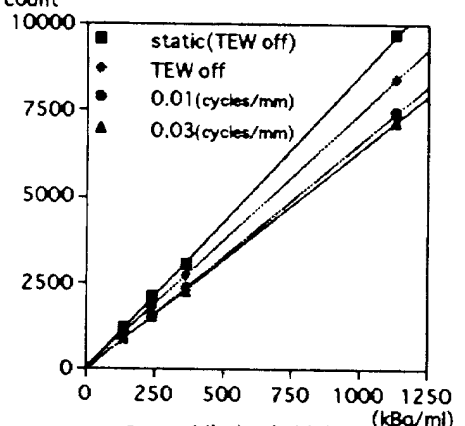

fig.1謷度直線性

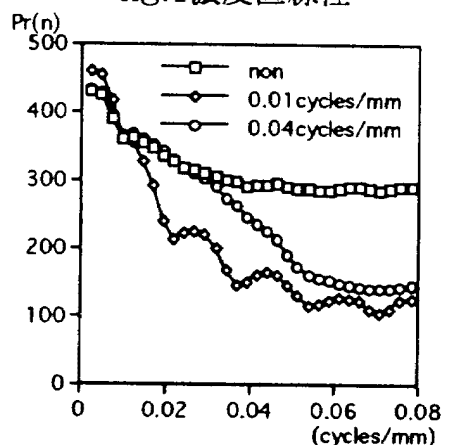

fig.2 Sub Windowの遮断周 波数を変化させたときのSub Window画像の周波数特性
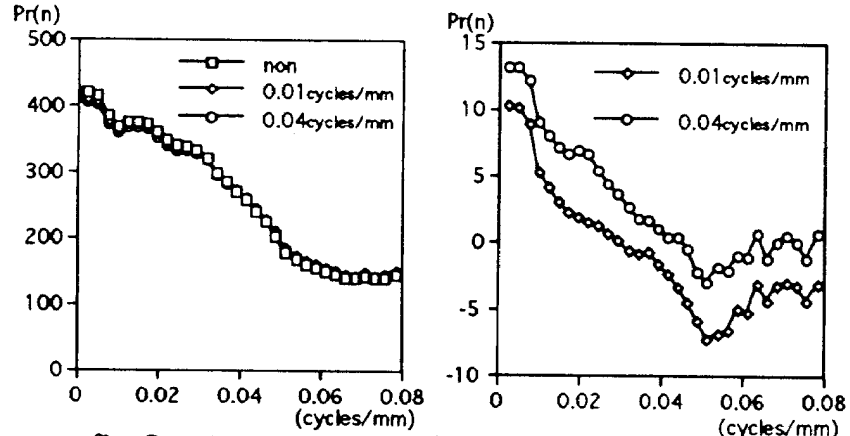

fig.3 SubWindowの遮断周波数を変化させたとき のMain Window画像の周波数特性

[まとめ]

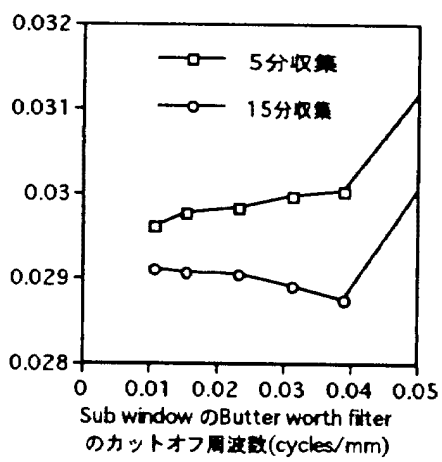

fig.4Sub Windowを変化させたとき のNMSE

1.MainWindow $24 \%$ とした外側に設定したLowerWindowのPr(n)は信号成分がBrain phantomでは0.04cycles/ $\mathrm{mm}$ まで存在する為、それに適したフィルター処理が必要になる。

2.Pr(n)よりSubWindowのフィルターはBW(0.04/8)が良いが、countにより変える必要がある。

3.蕽度直線性よりLowerWindowのフィルターはBW(0.04/8)とBW(0.01/8)で差は認められない。 4.画像の周波数特性、濃度直線性の結果より、LowerWindowのBW(0.04/8)が有用と考えられた。 